\title{
Article
}

\section{Multivariate Analysis on The Determinants of Work Fatigue Factors for Nurses Inpatient Care at RSUD Arifin Achmad Hospital Pekanbaru}

\section{Article Info}

Article history :

Received April 13, 2020

Revised April 20, 2020

Accepted April 22, 2020

Published April 30, 2020

Keywords :

multivariate analysis, work fatigue, age, gender, length of service, nutritional status, work shift

\section{Devi Purnamasari ${ }^{*}{ }^{1}$, Tjipto Suwandi ${ }^{2}$, Endang Purwanti Rahayu $^{2}$}

${ }^{1}$ Department of Radiology Engineering, Sekolah Tinggi Ilmu Kesehatan (STIKES) Awal Bros Pekanbaru, Indonesia. ${ }^{2}$ Postgraduate Study Program in Public Health, Sekolah Tinggi Ilmu Kesehatan (STIKES) Hangtuah Pekanbaru, Indonesia

Abstract. Work fatigue is one of the few symptoms that is often found in a hospital or hospital. Based on data almost every year as many as 2 million workers die due to accidents caused by fatigue. This research aims to analyze the relationship of age, sex, years of work, nutritional status and work shifts to work fatigue. This research is a quantitative observational analytic study with an analytic cross-sectional study design and a sample size of 60 people. Primary data were collected by direct observation, interviews with the KAUPK2 questionnaire and measurement of Lassidaya L77. The results of bivariate analysis showed a relationship between age and nurse work fatigue $(p=0.026)$. There was no gender relationship $(p=0.552)$, years of service $(p=0.104)$, nutritional status $(p=0.288)$ and work shift $(p=0.132)$ with work fatigue. Arifin Achmad Hospital ( $\mathrm{p}=0.009)$ POR 12,199 (95\%: 1,847 - 80,575). Counfonding work shifts with tenure. There is no relationship between sex and nutritional status with the incidence of work fatigue. Nutritional status $(\mathrm{p}=$ $0.571)$, POR 1.458 (95\%: 0.395 - 5.379). Nutritional status ( $\mathrm{p}=$ $0.866) 1.062$ POR (95\%: 0.527 - 2.140). The age variable was not included in the multivariate analysis because it was homogeneous. From the results of the analysis it was concluded that the working period $\geq 10$ years affects work fatigue compared to ten years $<10$ years.

This is an open acces article under the $C C-B Y$ license.

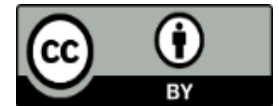

This is an open access article distributed under the Creative Commons 4.0 Attribution License, which permits unrestricted use, distribution, and reproduction in any medium, provided the original work is properly cited. (C2020 by author. 
Corresponding Author :

Devi Purnamasari

Department of Radiology Engineering, Sekolah Tinggi Ilmu Kesehatan

(STIKES) Awal Bros Pekanbaru, Indonesia

Email : devipurnamasari77@gmail.com

\section{Introduction}

Work fatigue is one of the occupational health and safety issues that can be a risk factor for accidents at work. According to the Ministry of Manpower and Transmigration in based on data on work accidents recorded in Indonesia every day an average of 414 occupational accidents is $22.7 \%$ due to fatigue that is quite high. Where the determinants of work fatigue vary from factors of work environment that are inadequate to work (noise, lighting and temperature), rest periods and disproportionate working hours can increase the degree of work discharge, the health of workers who are not monitored properly, giving Inadequate nutrition can result in work fatigue, workload on workers should be adjusted to the physical and psychological abilities of workers, travel time to and from work, mental development that takes place periodically and work shifts[1-9].

Data from the International Labor Organization (ILO) 2003 shows that almost every year as many as two million workers die due to work accidents caused by fatigue. The feeling of sluggishness is one of several symptoms that are often found in clinics and hospitals. In a survey in the USA this fatigue is a big problem, $24 \%$ of all adults who come to the clinic suffer from chronic fatigue. Almost the same data can also be seen in a community survey in the UK which states that $25 \%$ of women and $20 \%$ of men complain that they always feel tired. Even though work fatigue is complained almost every day by workers in each work unit, but until 1990 work fatigue is still a mystery of the modern medical world which is full of obscurity in its causes[1-17].

Regional General Hospital (RSUD) Arifin Achmad Riau Province is a Class B education hospital, is a Riau provincial government institution that has duties and functions including individual health care efforts, a referral center of district and city hospitals in Riau Province. Arifin Achmad Regional Hospital of Riau Province has six service facility categories, namely, outpatient facilities, inpatient installation facilities, emergency treatment facilities, supporting facilities, diagnostic and therapeutic support facilities as well as superior facilities[10-17].

At Arifin Achmad Hospital, Riau Province, there are approximately 579 in-bed beds, with a total of 445 inpatient nurses including the coordinator and the room team leader. Where is the bed in Arifin Achmad Hospital Riau Province every day almost completely filled by patients, with the number of inpatients 29,952 people per year. Nurses in inpatient care have an important role in carrying out care for patients. With a high number of inpatients, nurses at the inpatient installation also have jobs with a high level of busyness, which has an impact on work fatigue for nurses. Based on the description above, researchers are interested in conducting research on the analysis of Nurse's Fatigue Determinant Factors in Inpatient Installation of Arifin Achmad Regional Hospital, Riau Province in 2017.

\section{Experimental Section}

This research is quantitative analytic observational, where the process to determine and interpret existing data or factors related to events. This type of analytic cross-sectional cross-sectional study design in which the independent variables and dependent variables are expressed at the same time to respondents who aim to find out certain factors and problems. Respondents in this study were nurses inpatient installation Arifin Achmad Regional Hospital of Riau Province, amounting to 431 people[18-22].

According to Isgiyanto (2009), determining the sample size if the population (N) is known, namely:

http://www.eksakta.ppj.unp.ac.id/index.php/eksakta 


$$
\begin{aligned}
& \mathrm{n}=\frac{\mathrm{NZ}^{2}{ }_{1-\alpha / 2} \mathrm{P}(1-\mathrm{P})}{\mathrm{N} \mathrm{d}^{2}+\mathrm{Z}^{2}{ }_{1-\alpha / 2} \mathrm{P}(1-\mathrm{P})} \\
& \mathrm{n}=\frac{431(1,96){ }^{2} \times 0,8(1-0,8)}{431(0,1)^{2}+(1,96)^{2} \times 0,8(1-0,8)} \\
& \mathrm{n}=53,84 \approx 54 \\
& \mathrm{n} \quad=\text { large sample } \\
& \mathrm{N} \quad=\text { large population of } 431 \text { respondents }
\end{aligned}
$$

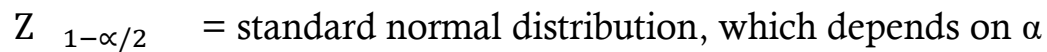

\begin{tabular}{|c|c|c|c|c|}
\hline No. & Variable & Operational Defenition & Scale & Category \\
\hline \multirow[t]{17}{*}{1} & Work & Complaints of fatigue due to work & Nominal & $0=$ light \\
\hline & Fatigue & felt by respondents based on & & $1=$ weight \\
\hline & & subjective symptoms as measured by & & \\
\hline & & KAUPK2 I, II, III. The question & & \\
\hline & & consists of 17 questions with 6 & & \\
\hline & & alternative answer choices worth 1- & & \\
\hline & & 6 , if the total value is: & & \\
\hline & & - 18-34 tired & & \\
\hline & & -> 35 are very tired & & \\
\hline & & Feelings of fatigue are measured & & $0=$ light \\
\hline & & objectively using the Lakassidaya & Nominal & $1=$ weight \\
\hline & & L77 reaction time by slowing down & & \\
\hline & & the respondent's time to respond to & & \\
\hline & & light and sound stimulation in & & \\
\hline & & milliseconds, if the total value is: & & \\
\hline & & $-<410$ tired & & \\
\hline & & $-\geq 410$ are very tired & & \\
\hline
\end{tabular}

$$
\begin{aligned}
& \text {, confidence interval }(1-\alpha)=95 \% \text {, then } \alpha=5 \% \text {, so that } \\
& \mathrm{Z}_{1-\propto / 2}=1,96 \\
& \mathrm{P}=\text { the proportion of events is } 80 \%=0,8 \\
& \mathrm{~d}=\text { the magnitude of the deviation (absolute) received is } 0.1
\end{aligned}
$$

Based on the sample size calculation, the number of samples obtained was 54 respondents and rounded to 60 respondents (Ariawan, 1998).

Table 1. Operational Definition of Dependent Variables in Work Fatigue Research 
Table 2. Operational Definitions of Independent Variables in Work Fatigue Research

\begin{tabular}{|c|c|c|c|c|}
\hline No & Variable & Operational Definition & Scale & Category \\
\hline 1 & Age & $\begin{array}{l}\text { The length of time the respondent lived } \\
\text { from birth until this study was conducted } \\
\text { which was calculated from the } \\
\text { respondent's birthday using a unit of year }\end{array}$ & Nominal & $\begin{array}{l}0=<40 \text { thn } \\
1=\geq 40 \text { thn }\end{array}$ \\
\hline 2 & Sex & $\begin{array}{l}\text { Identified physical marks on respondents } \\
\text { who were born from birth }\end{array}$ & Nominal & $\begin{array}{l}0=\text { Male } \\
1=\text { Female }\end{array}$ \\
\hline 3 & $\begin{array}{l}\text { Years of } \\
\text { Service }\end{array}$ & $\begin{array}{l}\text { The length of time the respondent } \\
\text { underwent the nursing profession in the } \\
\text { inpatient installation of Arifin Achmad } \\
\text { Hospital }\end{array}$ & Nominal & $\begin{array}{l}0=<10 \text { years } \\
1=\geq 10 \text { years }\end{array}$ \\
\hline 4 & Nutrition & $\begin{array}{l}\text { The nutritional state of the respondent at } \\
\text { the time of Body Mass Index } \\
\text { measurement with the formula weight } \\
\text { divided by height squared (meters) } \\
0=\text { normal } 18.5-24.9 \\
1=\text { malnutrition if }<18.5 \\
2=\text { over nutrition } \geq 25.0\end{array}$ & Ordinal & $\begin{array}{l}0=\text { Normal } \\
1=\text { Less } \\
2=\text { More } \\
\text { nutrition }\end{array}$ \\
\hline 5 & Shift & $\begin{array}{l}\text { The work time taken by the respondent is } \\
\text { in accordance with the division of work } \\
\text { schedules } \\
0=\text { morning shift } 07.30-14.00 \mathrm{am} \\
1=\text { afternoon shift } 14: 00-21: 00 \mathrm{am} \\
2 \text { = night shift } 21: 00-07.30 \mathrm{am}\end{array}$ & Ordinal & $\begin{array}{l}0=\text { Morning } \\
1=\text { Afternoon } \\
2=\text { Night }\end{array}$ \\
\hline
\end{tabular}

The type of data collected for this research are primary data and secondary data. Primary data are independent variables (age, gender, years of service, nutritional status, and work shifts) collected using a questionnaire containing closed questions through structured interviews and filling in KAUPK2 where respondents answered 17 questions with 6 alternative answers, each worth 1 (never), 2 (rarely), 3 (rarely), 4 (yes, quite often), 5 (yes, often) and 6 (yes, very often).

Measurement of feelings of fatigue is also assisted by using the Lakassidaya L77 Reaction Timer tool which is carried out after the nurse has finished her work on that day.

Secondary data is data of nurses in the Inpatient Installation of Arifin Achmad Hospital in Riau Province which is obtained by requesting data from the Arifin Achmad Regional Hospital in Riau Province. Ways of collecting data and instruments used for primary and secondary data collection are shown in the following table: 
Table 3. Data collection in the Determinant Research Factors of Work Fatigue Nurse Inpatient Installation Arifin Achmad Hospital Riau Province in 2017

\begin{tabular}{|c|c|c|c|}
\hline Data Type & Variable & How to get data & Instrument \\
\hline \multirow[t]{3}{*}{ Primary } & Fatigue & $\begin{array}{l}\text { Fill Quetioner } \\
\text { Reaction Timer }\end{array}$ & $\begin{array}{ll}\text { - } & \text { KAUPK2 } \\
\text { - } & \text { Lakassidaya L77 }\end{array}$ \\
\hline & Age & Fill Quetioner & Quetioner \\
\hline & Sex & Fill Quetioner & Quetioner \\
\hline \multirow{3}{*}{ data } & Years of Service & Fill Quetioner & Quetioner \\
\hline & Nutritional Status & Pengukuran IMT & Quetioner \\
\hline & Works Shift & Fill Quetioner & Quetioner \\
\hline $\begin{array}{l}\text { Secondary } \\
\text { Data }\end{array}$ & $\begin{array}{l}\text { Nurse data at } \\
\text { Arifin Achmad } \\
\text { Regional Hospital } \\
\text { in Riau Province }\end{array}$ & $\begin{array}{l}\text { Requesting the Arifin } \\
\text { Achmad Regional } \\
\text { Hospital of Riau } \\
\text { Province }\end{array}$ & - \\
\hline
\end{tabular}

After the data is collected, then computerized data processing is carried out through a process with the following stages; Editing is done by checking the completeness of the answers to the questionnaire filled out by the respondent with the aim that the incoming data can be processed correctly so that the data processing is grouped using the regulatory aspects. At this stage is the activity of checking the validity of incoming data. The checks carried out in this study were by filling in KAUPK2 and checking the reaction time using Lakassidaya L77.

Coding provides code in each category for each variable in the order of the respondent's number, with the intention of making it easier for researchers to process data. For age, sex, work period, nutritional status, work shift variables were conducted using interviews using the KAUPK2 questionnaire, while fatigue used reaction time measurements with Lakassidaya L77.

Processing, is an activity to process data so that it can be analyzed. The researcher enters data from the questionnaire filling into the master table or computer database and performs univariate analysis, bivariate analysis and multivariate analysis.

Cleaning, is an activity of checking back data that has been entered, whether there is an error or not. At this stage the researcher is assisted by fellow students.

Tabulating, is the stage of organizing data activities in such a way so that it can easily be numbered, organized, and arranged to be presented and analyzed. At this stage the researchers were assisted by colleagues from Epidiomology Masters

Multivariate analysis in this study was used to see the independent variables (age, sex, years of service, nutritional status, and work shifts) that were most dominantly related to the dependent variable (work fatigue), calculating the magnitude of risk with the Prevalence Odds Ratio (POR) rate and eliminate the influence of the troublemaker variable. Multivariate analysis conducted was multiple logistic regression, following two stages, bivariate selection and multivariate modeling. In multivariate modeling explained the examination of confounding or confounding variables and interactions between certain variables. If the independent variables with two categories were performed multivariate logistic regression analysis without dummy. If there are more variables with two categories, the multivariate test must be preceded by doing a dummy on the variable. In this 
study before multivariate analysis was conducted, a dummy was performed on variables consisting of categories.

\section{Results and Discussion}

Multivariate analysis aims to see or study the relationship of several independent variables simultaneously with one or several dependent variables. In this research, the multivariate analysis conducted was Multiple logistic regression by following 2 stages, namely: Bivariate Selection and multivariate modeling.

\subsection{Bivariate Selection}

Each independent variable is analyzed bivariately with the dependent variable. If the bivariate results produce $\mathrm{p}$ value $<0.25$, then the variable is entered into the multivariate stage. For independent variables whose bivariate selection results in $p$ values $>0.25$ but substantially important, these variables can be included in the multivariate model. Bivariate selection uses a simple logistic regression test, a mathematical model used to analyze the relationship of one or several independent variables with a categorical dependent variable. The results of the bivariate selection of 5 independent variables can be seen in Table 4 .

Table 4. Results of bivariate selection of independent variables with work fatigue in nurses at the Arifin Achmad Regional Hospital in Riau Province in 2017

\begin{tabular}{clcc}
\hline No & \multicolumn{1}{c}{$\begin{array}{c}\text { Independent } \\
\text { Variable }\end{array}$} & P Value & Information \\
\hline 1 & Age & 0,007 & Candidate \\
\hline 2 & Sex & 0,370 & - \\
\hline 3 & Years of Service & 0,049 & Candidate \\
\hline 4 & Nutritional Status & 0,269 & - \\
\hline 5 & Work Shift & 0,127 & Candidate \\
\hline
\end{tabular}

Based on the table above only 3 variables are candidates for the multivariate stage (age, years of service, shifts) but for the age variable will not be included in the multivariate stage because it is homogeneous. Meanwhile, gender and nutritional status variables will be included in the multivariate stage because they are considered as important substances.

\subsection{Multivariate Modeling}

Multivariate Modeling of 1

Multivariate 1 modeling is modeling by including all candidate variables.

Table 5. Multivariate Modeling Analysis 1

\begin{tabular}{lccc}
\hline $\begin{array}{l}\text { Independent } \\
\text { Variable }\end{array}$ & P Value & POR & $(95 \% \mathrm{Cl})$ \\
\hline Sex & 0,585 & 1,441 & $0,388-5,354$ \\
\hline $\begin{array}{l}\text { Years of } \\
\text { Service }\end{array}$ & 0,013 & 11,301 & $1,664-76,735$ \\
\hline $\begin{array}{l}\text { Nutritional } \\
\text { Status }\end{array}$ & 0,868 & 1,062 & $0,527-2,140$ \\
\hline Shift & 0,027 & & \\
\hline
\end{tabular}




\begin{tabular}{cccc}
\hline Shift 1 & 0,066 & 4,905 & $0,903-26,650$ \\
Shift 2 & 0,007 & 12,566 & $1,990-79,348$ \\
\hline
\end{tabular}

The results of the analysis show that the nutritional status variable has the greatest $p$ value of 0.866 so that it is excluded from multivariate modeling.

\section{Multivariate Modeling of 2}

In Table 6 shows the analysis of the relationship of work fatigue with the independent variables gender, length of work and work shifts.

Table 6. Multivariate Modeling Analysis 2

\begin{tabular}{lccc}
\hline Independent Variable & P Value & POR & $(95 \% \mathrm{Cl})$ \\
\hline Sex & 0,571 & 1,458 & $0,395-5,379$ \\
\hline Years of Service & 0,012 & 11,519 & $1,715-77,391$ \\
\hline Shift & 0,027 & & \\
$\quad$ Shift 1 & 0,61 & 4,982 & $0,926-26,813$ \\
Shift 2 & 0,007 & 12,527 & $1,985-79,053$ \\
\hline
\end{tabular}

To ascertain whether nutritional status variables are not included in the model or maintained as confounding, changes in POR values will be seen.

Table 7. Changes in POR values after multivariate analysis

\begin{tabular}{lccc}
\hline Independent Variable & $\begin{array}{c}\text { POR has } \\
\text { nutritional } \\
\text { status }\end{array}$ & $\begin{array}{c}\text { POR without } \\
\text { nutritional } \\
\text { status }\end{array}$ & POR \% change \\
\hline Sex & 1,441 & 1,458 & $1,1 \%$ \\
\hline Years of Service & 11,301 & 11,519 & $1,9 \%$ \\
\hline Shift & & & \\
Shift 1 & 4,905 & 4,982 & $1,5 \%$ \\
Shift 2 & 12,566 & 12,527 & $0,31 \%$ \\
\hline
\end{tabular}

With the results of the POR comparison, no one is $>10 \%$ and thus the nutritional status variable is excluded in multivariate modeling.

Multivariate Modeling of 3

In multivariate modeling 3 gender variables ( $p$ value 0.585 ) were excluded from modeling. 
Table 8. Multivariate Modeling Analysis 3

\begin{tabular}{lccc}
\hline \multicolumn{1}{c}{ Independent Variable } & P Value & POR & $(95 \% \mathrm{Cl})$ \\
\hline Years of Service & 0,009 & 12,199 & $1,847-80,575$ \\
\hline Shift & 0,027 & & \\
$\quad$ Shift 1 & 0,064 & 4,866 & $0,911-25,996$ \\
Shift 2 & 0,007 & 12,433 & $1,978-78,130$ \\
\hline
\end{tabular}

To ascertain whether gender variables are not included in the model or maintained as confounding, changes in POR values will be seen.

Table 9. Changes in POR values after multvariate analysis

\begin{tabular}{cccc}
\hline $\begin{array}{c}\text { Independent } \\
\text { Variable }\end{array}$ & POR has sex & $\begin{array}{c}\text { POR without } \\
\text { sex }\end{array}$ & POR \% changes \\
\hline $\begin{array}{c}\text { Years of } \\
\text { Service }\end{array}$ & 11,519 & 12,199 & $5,9 \%$ \\
\hline $\begin{array}{c}\text { Shift } \\
\text { Shift } 1\end{array}$ & 4,982 & 4,866 & $2,3 \%$ \\
Shift 2 & 12,517 & 12,433 & $0,75 \%$ \\
\hline
\end{tabular}

After comparing the POR values, none were $>10 \%$, thus gender variables were excluded in multivariate modeling.

\section{Multivariate Modeling of 4} modeling.

In multivariate modeling 4 work shift variables ( $p$ value 0.27 ) that will be excluded from

Table 10. Multivariate Modeling Analysis 4

\begin{tabular}{lccc}
\hline Independent Variable & P Value & POR & $(95 \% \mathrm{Cl})$ \\
\hline Years of Service & 0,63 & 3,857 & $8,927-16,048$ \\
\hline
\end{tabular}

To ascertain whether the work shift variable is not included in the model or maintained as confounding, a comparison of POR values will be seen.

Table 11. Changes in POR values after multivariate analysis

\begin{tabular}{lccc}
\hline \multicolumn{1}{c}{$\begin{array}{c}\text { Independent } \\
\text { Variable }\end{array}$} & $\begin{array}{c}\text { POR has } \\
\text { shift }\end{array}$ & $\begin{array}{c}\text { POR without } \\
\text { shift }\end{array}$ & POR \% changes \\
\hline $\begin{array}{l}\text { Years of } \\
\text { Service }\end{array}$ & 12,199 & 3,857 & $68,4 \%$ \\
\hline
\end{tabular}


Based on Table 12 there is a change in POR value of more than $10 \%$, then the work shift variable is a confounding variable and will be re-entered into multivariate modeling.

Table 12. Last Multivariate Analysis Determinants of Work Fatigue Factors of Nurses Inpatient Installation of Arifin Achmad Regional Hospital Riau Province 2017

\begin{tabular}{lccc}
\hline $\begin{array}{c}\text { Independent } \\
\text { Variable }\end{array}$ & P Value & POR & $(95 \% \mathrm{Cl})$ \\
\hline Years of Service & 0,009 & 12,199 & $1,847-80,575$ \\
\hline Shift & 0,027 & & \\
$\quad$ Shift 1 & 0,064 & 4,866 & $0,911-25,996$ \\
Shift 2 & 0,007 & 12,433 & $1,978-78,130$ \\
\hline
\end{tabular}

The interpretation of multivariate analysis is the dominant variable affecting the incidence of work fatigue in nurses, namely work period. Nurses who work more than $\geq 10$ years at risk 3.8 times experience work fatigue compared to nurses who worked $<10$ years. This means nurses with ten years masa tenure have a significant relationship to the level of heavy work fatigue compared with nurses with ten years $<10$ years with a statistical value $(p=0.009)$ POR 3.857 means nurses with ten years masa tenure have a risk of severe fatigue 3.8 times compared to the nurse's tenure $<10$ years. There is evidence that so far nurses who work for years only perform nursing tasks to patients so that the accumulation of monotonous work that results in heavy fatigue at the nurses. In this case the work shift is confounding the working period. The absence of division of work shifts that are adjusted to the length of work can affect the high level of work fatigue for nurses who work longer. The number of nurses who are not adjusted to the needs of work at the time the work shift takes place, the absence of a substitute nurse when other nurses cannot work can also affect the work fatigue of nurses. The relationship between work period and work shift with work fatigue in nurses Arifin Achmad Hospital in Riau Province can be seen in the following figure 1.

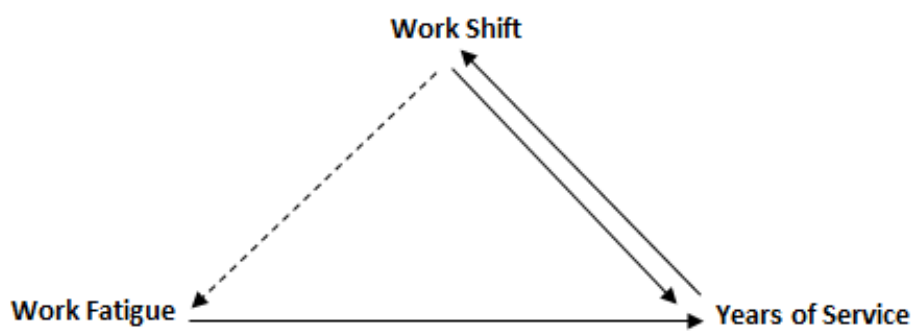

Figure 1. Relationship between work tenure and work shift with work fatigue

In the picture above it can be explained that the nurse's length of service is directly related to the nurse's work shift. While work shifts is a counfonding of work fatigue. 


\section{Conclusion}

Based on the description of the results and discussion, the age variable is significantly related to Work Fatigue in Inpatient Installation Nurses of Arifin Achmad Regional Hospital of Riau Province in 2017 when analyzing bivariate selection, but not included in the multivariate modeling because it is homogeneous. The sex variable is not significantly related to work fatigue. Work Fatigue in Nurses in Inpatient Installation of Arifin Achmad Regional Hospital, Riau Province in 2017. Variable length of service is significantly related to Work Fatigue in Inpatient Nurses in Arifin Achmad Regional Hospital in Riau Province in 2017. Working period of more than 10 years has a risk of 3.8 times experiencing work fatigue compared to nurses who have worked less than 10 years. Nutritional status variable is not significantly related to Work Fatigue in Inpatient Nurse Installation Arifin Achmad Hospital Riau Province in 2017 Work shift variable is a counfonding variable in this study.

\section{Acknowledgement}

Thank you to Prof. Tjipto Suwandi and Dr. Endang Purwanti Rahayu as a mentor when completing the Master at STIKES Hang Tuah Pekanbaru.

\section{References}

[1] Al Ma'mari Q, Sharour LA, Al Omari O.(2020). Fatigue, burnout, work environment, workload and perceived patient safety culture among critical care nurses. British journal of nursing;29:28-34.

[2] Austin S, Fernet C, Trepanier SG, Lavoie-Tremblay M.(2020). Fatigue in new registered nurses: A 12-month cross-lagged analysis of its association with work motivation, engagement, sickness absence and turnover intention. Journal of nursing management;28:606-14.

[3] Dohrmann SB, Herttua K, Leppin A.(2020). Is physical and psychological work stress associated with fatigue in Danish ferry ship employees? International maritime health;71:4655.

[4] Gander P, O'Keeffe K, Santos-Fernandez E, Huntington A, Walker L, Willis J.(2020). Development and evaluation of a matrix for assessing fatigue-related risk, derived from a national survey of nurses' work patterns. International journal of nursing studies:103573.

[5] Glimne S, Brautaset R, Osterman C.(2020). Visual fatigue during control room work in process industries. Work;65:903-14.

[6] Jacobsen HB, Glette M, Hara KW, Stiles TC.(2020). Metacognitive Beliefs as Predictors of Return to Work After Intensive Return-to-Work Rehabilitation in Patients With Chronic Pain, Chronic Fatigue and Common Psychological Disorders: Results From a Prospective Trial. Frontiers in psychology; 11:70.

[7] Lee E, Jang I.(2020). Nurses' Fatigue, Job Stress, Organizational Culture, and Turnover Intention: A Culture-Work-Health Model. Western journal of nursing research;42:108-16.

[8] Martinez CL, Moraga SP, Paredes CS, Vasquez AS, Villarroel CMV.(2020). Occupational fatigue and work absenteeism in female assistant nurses of a high-complexity hospital, Chile. Ciencia \& saude coletiva;25:243-9.

[9] May AM.(2020). Transferring effective interventions for cancer-related fatigue from the adjuvant to the advanced cancer session: does it work? Annals of oncology : official journal of the European Society for Medical Oncology;31:9-10.

[10] Mehdizadeh A, Vinel A, Hu Q, Schall MC, Jr., Gallagher S, Sesek RF.(2020). Job rotation and work-related musculoskeletal disorders: a fatigue-failure perspective. Ergonomics;63:46176. 
[11] MJ VDB, Signal TL, Gander PH.(2020). Fatigue risk management for cabin crew: the importance of company support and sufficient rest for work-life balance-a qualitative study. Industrial health;58:2-14.

[12] Morimoto A, Watanabe S, Ohno Y, Godai K, Hatamochi C, Sugimoto Y, et al.(2020). Associations among work-related stress and mental fatigue, and regular exercise in Japanese employees with or without diabetes. Diabetology international;11:105-13.

[13] Obeid S, Akel M, Haddad C, Fares K, Sacre H, Salameh P, et al.(2020). Factors associated with alcohol use disorder: the role of depression, anxiety, stress, alexithymia and work fatiguea population study in Lebanon. BMC public health;20:245.

[14] Okhiria M, Truszczynska-Baszak A, Tarnowski A.(2020). Assessment of work-related fatigue in Polish physiotherapists and of its effect on their diagnostic accuracy and physiotherapy planning. International journal of occupational safety and ergonomics : JOSE;26:406-12.

[15] Ramos Nogueira LF, Marqueze EC.(2019). Night work and fatigue symptoms are associated with clinical monitoring indicators among workers living with HIV. Revista brasileira de medicina do trabalho : publicacao oficial da Associacao Nacional de Medicina do TrabalhoANAMT; 17:160-9.

[16] Yamada K, Adams H, Ellis T, Clark R, Sully C, Sullivan MJL.(2020). Reductions in Fatigue Predict Occupational Re-engagement in Individuals with Work-Related Musculoskeletal Disorders. Journal of occupational rehabilitation;30:135-45.

[17] Zolnierczyk-Zreda D, Jedryka-Goral A, Bugajska J, Bedynska S, Brzosko M, Pazdur J.(2020). The relationship between work, mental health, physical health, and fatigue in patients with rheumatoid arthritis: A cross-sectional study. Journal of health psychology;25:665-73.

[18] Lin D, Qi SY, Hong L, Lin S, Lin LL, Mo YC.(2020). [Multivariate statistical analysis of Evans blue exudation spots and acupoint sensitization distribution in rats with acute intestinal mucosal injury]. Zhen ci yan jiu = Acupuncture research;45:128-35.

[19] Riswahyuli Y, Rohman A, Setyabudi F, Raharjo S.(2020). Indonesian wild honey authenticity analysis using attenuated total reflectance-fourier transform infrared (ATR-FTIR) spectroscopy combined with multivariate statistical techniques. Heliyon;6:e03662.

[20] Wadood SA, Boli G, Xiaowen Z, Raza A, Yimin W.(2020). Geographical discrimination of Chinese winter wheat using volatile compound analysis by HS-SPME/GC-MS coupled with multivariate statistical analysis. Journal of mass spectrometry : JMS;55:e4453.

[21] Wang H, Chen M, Li J, Chen N, Chang Y, Dou Z, et al.(2020). Quality consistency evaluation of Kudiezi Injection based on multivariate statistical analysis of the multidimensional chromatographic fingerprint. Journal of pharmaceutical and biomedical analysis; $177: 112868$.

[22] Yang YY, Wu ZY, Zhang H, Yin SJ, Xia FB, Zhang Q, et al.(2020). LC-MS-based multivariate statistical analysis for the screening of potential thrombin/factor Xa inhibitors from Radix Salvia Miltiorrhiza. Chinese medicine;15:38. 